\title{
A comparison of latex slide tests for rheumatoid factors
}

\author{
D. J. LEA AND D. J. WARD \\ Rheumatology Unit, Robert Jones and Agnes Hunt Orthopaedic Hospital, Oswestry, Salop.
}

The latex slide test using particles coated with human $\gamma$-globulin provides a convenient screening test for serum rheumatoid factors and is widely used in place of the more discriminating but laborious titration using sheep cells coated with rabbit $\gamma$-globulin-the SCAT test. Standardization of the SCAT test is difficult, even though reference sera are now available (Anderson, Bentzon, Houba, and Krag, 1970). Commercial latex agents are not required to conform to any established standards and one comparison of the reagents showed an overall agreement of only 67 per cent. (Bach, Grieble, Zschocke, and Anderson, 1968). We felt that a comparative study of some currently available reagents using sera of known SCAT titre might demonstrate possible batch-to-batch differences in reagent from one source and differences between reagents from other sources and also might suggest a means of standardization.

\section{Materials and methods}

Sera were obtained for routine investigations in 1970 from patients attending clinics or admitted to the ward of the Rheumatology Unit. Routine latex tests were performed at that time using the method and reagents of one manufacturer. SCAT tests were performed on heat-inactivated absorbed sera using 1 per cent. sheep cells coated with rabbit antibody (Wellcome). Serial dilutions in saline were made in standard agglutination trays, which were incubated for 1 hour at $37^{\circ} \mathrm{C}$., shaken, and held overnight at $4^{\circ} \mathrm{C}$. before reading. The sensitizing dose of rabbit antierythrocyte serum was such that the majority of patients with classical or definite rheumatoid arthritis had titres of $1 / 16$ or more and most non-rheumatoid subjects had titres of $1 / 8$ or less. The sensitivity of the test was maintained by standardizing each new batch of rabbit antiserum with a reference panel of recent sera (Cathcart and O'Sullivan, 1965) and not by using a standard subagglutinating dose of antiserum. Latex reagent kits were purchased from three manufacturers (Hoechst, Hyland, and Mercia). Two were used as directed. The buffer in the third kit had a pH so different from the stated value that it was discarded and a buffer of a different manufacture used. Approximately equal volumes of latex reagents were delivered from the dropper bottles supplied and in the test approximately the same volume of dilute (5 per cent.) unheated serum in glycine buffer reagent was used. Only clear or strong agglutination patterns were recorded as positive.

\section{Results}

Repeat testing of different serum samples from the same patient and occasional re-titration of stored sera have never disclosed either unusually large random variations in titre or a steady long-term drift in the sensitivity of the SCAT test. Examination of previous routine results suggested that, by comparison, the latex reagent had undergone a marked decline in sensitivity. All sera with recorded latex results with SCAT titres in the range of $1 / 8$ to $1 / 128$, which had been examined over a period of several months in 1970 were re-tested with single bottles of three different current latex reagents (Table). One of these gave so few positive reactions that its use was curtailed. The results confirmed our previous impression that differences in sensitivity existed amongst the latex reagents tested.

Table Latex test results on sera grouped by $S C A T$ titre, percentage latex positive and (number positive) total)

\begin{tabular}{|c|c|c|c|c|}
\hline \multirow[t]{2}{*}{ Titre } & \multicolumn{4}{|c|}{ Manufacturer of reagent } \\
\hline & $\begin{array}{l}\text { Hoechst } \\
1970\end{array}$ & $\begin{array}{l}\text { Hoechst } \\
1971\end{array}$ & Hyland & Mercia \\
\hline $\begin{array}{r}128 \\
64 \\
32 \\
16 \\
8\end{array}$ & $\begin{array}{c}68(13 / 19) \\
69(11 / 16) \\
79(11 / 14) \\
27(4 / 15) \\
6(1 / 18)\end{array}$ & $\begin{array}{c}53(10 / 19) \\
40(6 / 15) \\
11(1 / 9) \\
11(1 / 9) \\
0(0 / 11)\end{array}$ & $\begin{array}{c}68(13 / 19) \\
56(9 / 16) \\
43(6 / 14) \\
33(5 / 15) \\
6(1 / 18)\end{array}$ & $\begin{array}{c}75(9 / 12) \\
88(14 / 16) \\
71(10 / 14) \\
20(3 / 15) \\
6(1 / 18)\end{array}$ \\
\hline
\end{tabular}

\section{Discussion}

The inconsistent results of the latex slide tests we have carried out upon sera from a restricted population of patients confirm the findings of Bach and others (1968) and suggest that latex slide test reagents used 
alone have little value as at present standardized commercially.

Many studies (e.g. Cats and Klein, 1970) have demonstrated the statistical association between the prognosis and clinical status of the rheumatoid individual and the serum agglutination titre in either the SCAT or latex-fixation test (LFT). Furthermore, it is generally, but not invariably, true that a serum with a high titre in one test has a high titre in the other, in spite of the fact that one test uses as antigen rabbit, and the other human, IgG immunoglobulin. It would thus be easier to standardize an agglutination test using a panel of sera of which the SCAT or LFT test titres were known, rather than by repeated reference to clinical information. From our limited study we judge that such a technique is probably sound and in practice should provide a basis for the routine control of latex slide test reagent.

The underlying reason for the general agreement between tests is that they reflect the immunological, not the clinical, status of the rheumatoid individual. The characteristic immune response in the disease is the production of an extremely heterogeneous mixture of agglutinating and non-agglutinating antibodies able to react with the IgG immunoglobulins of different species. A single agglutination test detects only some of these antibodies and therefore no such test can be considered in any sense quantitative, as is sometimes stated.

Two tests which use the same IgG antigen may occasionally give different results if the orientation of this antigen on the particle surface differs in the two cases, as in the study of Ball, de Graaf, Valkenburg, and Westendorp Boerma (1962). Bach and others (1968) found that two similar latex reagents differed greatly in their ability to detect the 'rheumatoid factors' in nonrheumatoid individuals, probably for the same reason. Because a satisfactory latex reagent should not react widely with nonrheumatoid sera, it seems desirable to use sera from liver and geriatric patients also in the testing procedure.

\section{Summary}

Latex slide tests of a panel of sera showed differences between commercial latex reagents, which were attributed to inadequate standardization. A new technique is suggested.

\section{References}

Anderson, S. G., Bentzon, M. W., Houba, V., And Krag, P. (1970) Bull. Wld Hlth Org., 42, 311 (International reference preparation of rheumatoid arthritis serum)

BACH, G., Grieble, H., ZsChOcKe, R., AND ANDERSON, T. (1968) Acta biol. med. germ., 20, 233 (Beitrag zum Problem der Standardisierung des Latex-Fixationstests zum Nachweis des Rheumafaktors. I. Vergleich dreier verschiedener Latex-Fixationstests und nähere Charakterisierung des Gammaglobulin-'Reaktant')

Ball, J., de GraAff, R., VAlKenburg, H. A., AND Westendorp BOERMa, F. (1962) Arthr. and Rheum., 5, 55 (Comparative studies of serologic tests for rheumatoid disease. I. A comparison of a latex test and two erythrocyte agglutination tests in a random population sample)

CathCart, E. S., AND O'Sullivan, J. B. (1965) Ibid., 8, 530 (Standardization of the sheep cell agglutination test. The use of pooled reference sera and hemagglutination trays)

CAts, A., AND Klein, F. (1970) Ann. rheum. Dis., 29, 663 (Quantitative aspects of the latex-fixation and Waaler-Rose tests) 